Abstracta Iranica Abstracta Iranica

Revue bibliographique pour le domaine irano-aryen

Volume 29 | 2008

Comptes rendus des publications de 2006

\title{
L'Oriente cristiano I. Panorama storico delle Chiese cristiane in Asia e in Africa. Bologne, Edizioni Studio Dominicani, 2005, $130 \mathrm{p}$.
}

Christelle Jullien

\section{OpenEdition}

1 Journals

Édition électronique

URL : http://journals.openedition.org/abstractairanica/30062

DOI : 10.4000/abstractairanica.30062

ISSN : 1961-960X

Éditeur :

CNRS (UMR 7528 Mondes iraniens et indiens), Éditions de l'IFRI

\section{Édition imprimée}

Date de publication : 15 mai 2008

ISSN : 0240-8910

Référence électronique

Christelle Jullien, «L'Oriente cristiano I. Panorama storico delle Chiese cristiane in Asia e in Africa. Bologne, Edizioni Studio Dominicani, 2005, 130 p. », Abstracta Iranica [En ligne], Volume 29| 2008, document 276, mis en ligne le 15 septembre 2008, consulté le 26 septembre 2020. URL : http://

journals.openedition.org/abstractairanica/30062 ; DOI : https://doi.org/10.4000/abstractairanica. 30062

Ce document a été généré automatiquement le 26 septembre 2020.

Tous droits réservés 
L'Oriente cristiano I. Panorama storico delle Chiese cristiane in Asia e in Africa. Bologne, Edizioni Studio Dominicani, 2005, $130 \mathrm{p}$.

Christelle Jullien

Ce tome dévolu à l'Orient chrétien offre surtout un survol général de l'histoire de l'Église d'Orient sous influence romaine à partir du IV ${ }^{e} s$. jusqu'à nos jours. L'A. s'intéresse aux provinces orientales de l'empire romain sous juridiction dioclétienne dans un premier chapitre. L'histoire de l'Église de Perse sous administration sassanide n'est pas abordée.

\section{INDEX}

Thèmes : 6.3. Autres religions

\section{AUTEURS}

CHRISTELLE JULLIEN

CNRS - Mondes iranien et indien - Paris 